\title{
Cough frequency and cough receptor sensitivity to citric acid challenge during a simulated ascent to extreme altitude
}

\author{
N.P. Mason*, P.W. Barry**, G. Despiau ${ }^{+}$, B. Gardette*, J-P. Richalet ${ }^{\#}$
}

\begin{abstract}
Cough frequency and cough receptor sensitivity to citric acid challenge during a simulated ascent to extreme altitude. N.P. Mason, P.W. Barry, G. Despiau, B. Gardette, J-P. Richalet. (C) ERS Journals Ltd 1999.

ABSTRACT: The aim of this study was to determine the frequency of cough and the citric acid cough threshold during hypobaric hypoxia under controlled environmental conditions.

Subjects were studied during Operation Everest 3. Eight subjects ascended to a simulated altitude of $8,848 \mathrm{~m}$ over 31 days in a hypobaric chamber. Frequency of nocturnal cough was measured using voice-activated tape recorders, and cough threshold by inhalation of increasing concentrations of citric acid aerosol. Spirometry was performed before and after each test. Subjects recorded symptoms of acute mountain sickness and arterial oxygen saturation daily. Air temperature and humidity were controlled during the operation.

Cough frequency increased with increasing altitude, from a median of 0 coughs (range 0-4) at sea level to 15 coughs (range 3-32) at a simulated altitude of $8,000 \mathrm{~m}$. Cough threshold was unchanged on arrival at $5,000 \mathrm{~m}$ compared to sea level (geometric mean difference (GMD) 1.0, 95\% confidence intervals (CI) $0.5-2.1, p=0.5$ ), but fell on arrival at 8,000 m compared to sea level (GMD 3.3, 95\% CI $1.1-10.3, p=0.043$ ). There was no relationship between cough threshold and symptoms of acute mountain sickness, oxygen saturation or forced expiratory volume in one second. Temperature and humidity in the chamber were controlled between $18-24 \mathrm{C}$ and $30-60 \%$, respectively.

These results confirm an increase in cough frequency and cough receptor sensitivity associated with hypobaric hypoxia, and refute the hypothesis that high altitude cough is due to the inhalation of cold, dry air. The small sample size makes further conclusions difficult, and the cause of altitude-related cough remains unclear. Eur Respir J 1999; 13: 508-513.
\end{abstract}

Numerous anecdotal reports exist of paroxysmal cough in climbers and travellers to high altitude [1-3] which may be severe enough to cause rib fractures $[2,3]$. The cause of this cough is not known, but has been attributed to the inspiration of cold, dry air, acute mountain sickness (AMS), high altitude pulmonary oedema (HAPO), bronchoconstriction or respiratory tract infection $[4,5]$.

In the first systematic study of cough at high altitude [6], an increase in cough frequency and cough receptor sensitivity was reported in a group of subjects ascending to Mount Everest Base Camp in Nepal at an altitude of 5,300 $\mathrm{m}$. However, because of the nature of the study, subjects at Base Camp were unavoidably exposed to cold, dry air, which has been shown to cause cough [7]. The aim of this study was therefore to measure cough frequency and cough receptor sensitivity in a group of subjects making a simulated ascent of Mount Everest $(8,848 \mathrm{~m})$ in a hypobaric chamber in which the temperature and humidity were controlled within normal sea level limits, and also to study the effects of extreme hypobaric hypoxia on cough.

\section{Methods}

\section{Subjects}

Eight subjects and one reserve were initially selected from healthy volunteers after physical and psychological

\begin{abstract}
*Service D'Anesthésie-Réanimation, Hôpital Tenon, Paris, France. **Dept of Child Health, University of Leicester, Leicester, UK. ${ }^{+}$Université Paul Sabatier, Faculté de Médecine, Toulouse, France. COMEX Industries, Marseillex, France. ${ }^{\#}$ ARPE, Laboratoire de Physiologie, UFR de Medicine, Bobigny, France.
\end{abstract}

Correspondence: N.P. Mason

Service D'Anesthésie-Réanimation

Hôpital Tenon

75020 Paris

France

Fax: 33156017007

Keywords: Citric acid

cough

high altitude

hypobaric chamber

Received: June 251998

Accepted after revision November 71998

Supported by grants from the Région Provence-Alps-Côte d'Azur and the Ministère de la Jeune et des Sports (France) assessment. All subjects had previous mountaineering exposure to high altitude. Subject demographics are shown in table 1 . None of the subjects had a history of atopy, asthma, exercise-induced bronchoconstriction or cough. Two subjects were occasional smokers, smoking $<20$ cigarettes $\cdot$ week $^{-1}$. None were taking regular medication.

\section{Ascent profile}

To minimize the time spent confined in the hypobaric chamber, after baseline tests at sea level, the subjects and reserve ascended by helicopter to the Vallot Observatory on Mont Blanc at 4,350 m for a 6-day period of acclimatization, spending the first night en route at the Cosmiques Hut $(3,613 \mathrm{~m})$. During the period at the Vallot one subject developed evidence of HAPO and was therefore withdrawn from the study being replaced by the reserve. These eight subjects then returned to Marseille where they spent a night before re-entering the chamber which was immediately depressurized to an altitude of $4,500 \mathrm{~m}$. Over the next 31 days the subjects ascended to the barometric equivalent of the summit of Mount Everest (altitude 8,848 $\mathrm{m}$, barometric pressure $33.6 \mathrm{kPa}(253 \mathrm{mmHg}))$. The ascent profile is illustrated in figure 1 . A period of recovery at $5,000 \mathrm{~m}$ was included prior to exposure to altitudes of $8,000 \mathrm{~m}$ and above, as would normally be adopted during a real mountaineering ascent to such altitudes. 
Table 1. - Subject demographics and previous altitude exposure

\begin{tabular}{|c|c|c|c|c|c|c|}
\hline $\begin{array}{l}\text { Sub- } \\
\text { ject } \\
\text { No. }\end{array}$ & $\begin{array}{l}\text { Age } \\
\text { yrs }\end{array}$ & $\begin{array}{c}\text { Height } \\
\mathrm{m}\end{array}$ & $\begin{array}{l}\text { Weight } \\
\mathrm{kg}\end{array}$ & $\begin{array}{c}\text { Smoker } \\
\text { cigarettes } \\
\text { day }^{-1}\end{array}$ & $\begin{array}{l}\text { Maximum } \\
\text { previous } \\
\text { altitude } m\end{array}$ & $\begin{array}{l}\text { Previous } \\
\text { altitude } \\
\text { illness }\end{array}$ \\
\hline 1 & 23 & 1.80 & 65 & 2 & 4807 & $\begin{array}{l}\text { No } \\
\text { Mild }\end{array}$ \\
\hline 2 & 37 & 1.83 & 75.5 & No & 8760 & $\begin{array}{c}\text { (insomnia) } \\
\text { Mild }\end{array}$ \\
\hline 3 & 25 & 1.90 & 81 & No & $>6000$ & $\begin{array}{c}\text { (headaches) } \\
\text { Mild }\end{array}$ \\
\hline 4 & 25 & 1.89 & 82 & No & $>6000$ & $\begin{array}{c}\text { (nausea) } \\
\text { Mild }\end{array}$ \\
\hline 5 & 26 & 1.76 & 72.5 & No & $>6000$ & $\begin{array}{c}\text { (nausea) } \\
\text { Mild }\end{array}$ \\
\hline 6 & 25 & 1.77 & 70 & 4 & 4100 & (headaches) \\
\hline 7 & 25 & 1.72 & 66 & No & 5200 & $\begin{array}{l}\text { No } \\
\text { Mild }\end{array}$ \\
\hline 8 & 26 & 1.76 & 78 & No & 4100 & (headaches) \\
\hline
\end{tabular}

\section{Nocturnal cough frequency}

Nocturnal cough frequency (NCF) was measured using portable voice-activated tape recorders (Panasonic RQL317, Panasonic, Bracknell, UK). Microphones were placed adjacent to the subjects head each night. The threshold for voice activation was adjusted to an appropriate sensitivity to be activated by coughing but not by extraneous noise. Subjects recorded the start and finishing times of recording on the tape. All recordings were stopped at 07:30 $\mathrm{h}$ if not otherwise indicated on the tape. Cough recording was performed at sea level, $5,000 \mathrm{~m}, 7,000 \mathrm{~m}$, recovery at $5,000 \mathrm{~m}$ and nights at 7,000 $\mathrm{m}$ after having spent the day at $8,000 \mathrm{~m}$. Tapes were replayed the next day by one of two observers and the total number of coughs noted, Coughs were easily distinguished from other noise. The number of coughs on the first technically satisfactory recording was taken as the cough frequency for each subject at that altitude. All tapes recorded at 7,000 m were assessed independently by both observers and good agreement in the recorded frequency of cough was observed between them $(\mathrm{k}=0.84)$ [8].

\section{Citric acid cough challenge}

Solutions of increasing concentrations of citric acid were inhaled via an ultrasonic nebulizer (Sonix 2000; Clement Clarke International, Harlow, UK) during a slow vital capacity inspiration over $5 \mathrm{~s}$ as previously described [6]. Citric acid was chosen as it is less likely to cause bronchoconstriction than other tussive agents such as capsaicin and is well tolerated. Beginning with a $0.3125 \mathrm{~g} \cdot \mathrm{L}^{-1}$ solution of citric acid in $0.9 \%$ saline, each solution was inhaled three times until the maximum concentration of $160 \mathrm{~g} \cdot \mathrm{L}^{-1}$ or the cough threshold was reached. The cough threshold was defined as the lowest concentration which provoked a cough providing that a cough was also provoked at the next concentration. Cough challenge was performed at sea level, $5,000 \mathrm{~m}$, recovery at 5,000 $\mathrm{m}$ and at $8,000 \mathrm{~m}$

The pattern of deposition of an aerosol within the airways changes with different inspiratory flow rates [9], and variations in the inspiratory flow rate alter the citric acid cough threshold (CACT) [10]. To maintain a reproducible stimulus to the airways a citric acid aerosol was administered using a single-breath technique from residual volume (RV) to total lung capacity (TLC) over $5 \mathrm{~s}$ [11]. This technique has been reported to give a reproducible result for the CACT [12].

Before and after each cough challenge forced expiratory volume in one second (FEV1), forced vital capacity (FVC) and peak expiratory flow (PEF) were recorded using a Micromedical Microloop turbine spirometer (Micromedical Ltd., Rochester, UK). The accuracy of this device is unaffected by low barometric pressures. Each day arterial oxygen saturation $\left(\mathrm{Sa}_{\mathrm{a}} \mathrm{O}_{2}\right)$ was recorded using a Hewlett Packard pulse oximeter (Hewlett Packard, Boulogne, France). The standardized Lake Louise Scoring System [13] was recorded to assess the severity of AMS. This assigned a score from 0 (no symptoms) to 3 (severe and incapacitating) to the following symptoms: headache; gastrointestinal symptoms (anorexia, nausea and vomiting); weakness or fatigue; vertigo or dizziness; and the quality of sleep from the preceding night.

The study was approved by the ethics committee of the University of Marseille. All subjects gave their written

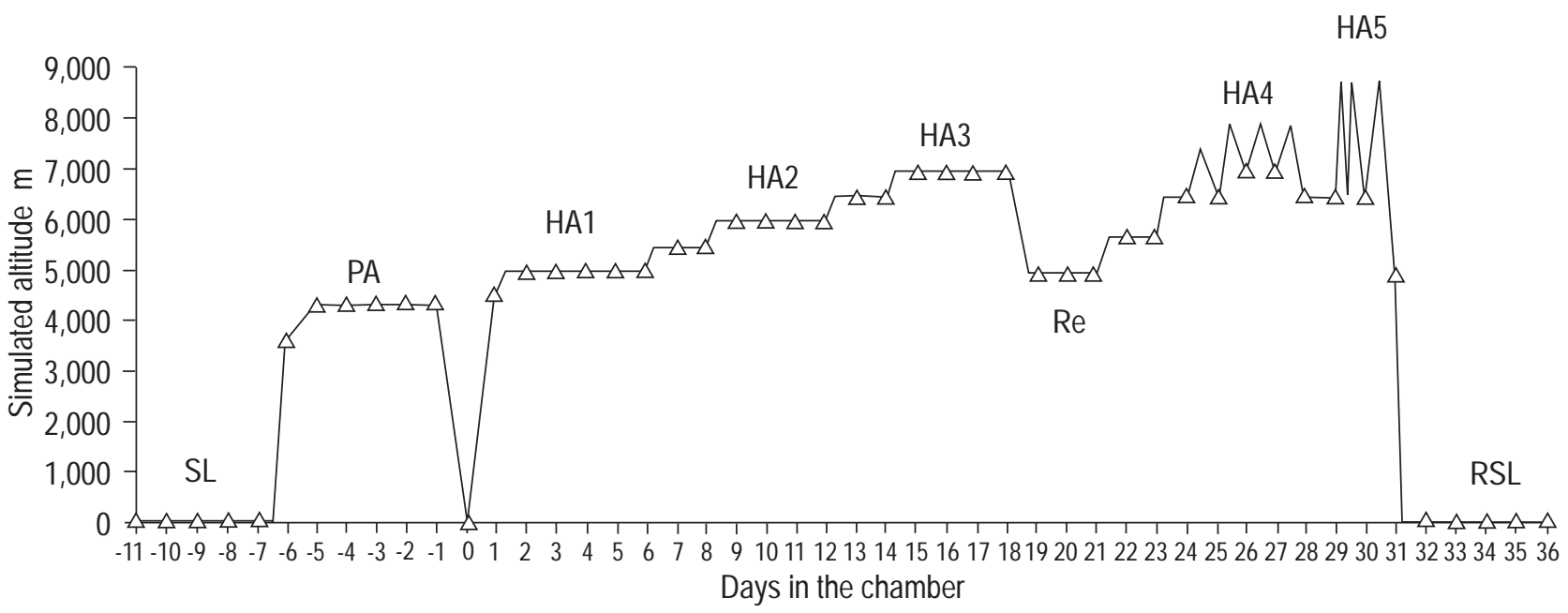

Fig. 1. - Operation Everest-3 ascent profile. SL: sea level, undertaken 10-16 March; PA: pre-acclimatization at Vallot, from 25-31 March; HA1 to HA5: high altitude, starting 1 April; Re: recovery before final assault; RSL: return to sea level on 2 May. $\Delta$ : night. 
informed consent. The hypobaric chamber was located at COMEX Industries (Marseille, France). Temperature and relative humidity in the chamber varied during the day and with changes in the chamber pressure, but were maintained between 18 and $24^{\circ} \mathrm{C}$ and $30-60 \%$, respectively. Two technicians monitored the environmental conditions at all times. The chamber was equipped with supplementary oxygen in all areas and three backup oxygenation systems. Any subject could be removed from the chamber within minutes.

\section{Completeness of the data}

Subject 1 developed a severe migraine-like headache which was associated with focal neurological signs on day 26 at an altitude of $8,000 \mathrm{~m}$ and the data at this altitude are therefore not available. NCF data are not available from subject 8 at $7,000 \mathrm{~m}$, from subjects 6 and 7 at $8,000 \mathrm{~m}$, owing to technical problems with the tape recorders. Subjects 2 and 8 did not collect NCF on return to sea level after 31 days in the chamber. Thus, NCF recordings were made on eight subjects at sea level, $5,000 \mathrm{~m}$, and return to $5,000 \mathrm{~m}$, on seven subjects at 7,000 m; on five subjects at $8,000 \mathrm{~m}$; and on six subjects on return to sea level. CACT was not available for subject 8 on return to $5,000 \mathrm{~m}$, and CACT was therefore measured on eight subjects at sea level and 5,000 m, and on seven subjects at return to 5,000 $\mathrm{m}$ and $8,000 \mathrm{~m}$.

\section{Statistical analysis}

NCF was normalized by logarithmic transformation, and the effect of altitude on NCF was determined by analysis of variance. Fisher's pairwise comparisons were used to give the $95 \%$ confidence intervals (CI) for the difference between the mean NCFs at different altitudes. The values are expressed as the geometric mean differences (GMD) and represent the ratio between the geometric means.

The distribution of cough threshold values was positively skewed, and was normalized by logarithmic transformation of the data. Cough thresholds for the subjects at each altitude are described by the mean of the logarithm of the cough threshold (the geometric mean). Differences between groups studied at different locations or times are given as the GMD and 95\% CI. Cough thresholds for each individual were compared using paired t-tests, without correction for multiple comparisons.

The relationship between change in cough threshold from sea level and AMS score, $\mathrm{Sa}_{\mathrm{a}, \mathrm{O}_{2}}$ and lung function (prior to the CACT) were compared using a general linear model [8]. The model allows multiple factors to be analysed to explain the observed change in cough threshold at altitude. Terms for subject number, altitude, AMS score, oxygen saturation and lung function were included in the model. Terms were fitted to the model by backwards stepwise regression. Data was analysed using Minitab Release 10 (Clecom Ltd., Birmingham, UK). Statistical significance was assumed at $\mathrm{p}<0.05$.
Table 2. - Nocturnal cough frequency

\begin{tabular}{lcrrccc}
\hline $\begin{array}{l}\text { Subject } \\
\text { No. }\end{array}$ & \begin{tabular}{c} 
Altitude $\mathrm{m}$ \\
\cline { 2 - 7 } \\
level
\end{tabular} & 5,000 & 7,000 & $\begin{array}{c}\text { Return to } \\
5,000\end{array}$ & 8,000 & $\begin{array}{c}\text { Return to } \\
\text { sea level }\end{array}$ \\
\hline 1 & 2 & 0 & 12 & 7 & - & 0 \\
2 & 0 & 2 & 18 & 4 & 3 & - \\
3 & 2 & 9 & 10 & 3 & 12 & 0 \\
4 & 0 & 10 & 32 & 3 & 32 & 0 \\
5 & 3 & 2 & 18 & 2 & 9 & 0 \\
6 & 0 & 13 & 11 & 2 & - & 0 \\
7 & 0 & 8 & 8 & 2 & - & 1 \\
8 & 0 & 1 & - & 0 & 27 & - \\
Median & 0 & 5 & 12 & 2.5 & 12 & 0 \\
\hline
\end{tabular}

\section{Results}

\section{Nocturnal cough frequency}

Analysis of variance showed that NCF (table 2) increased from sea level (median number of coughs 0 , range $0-3)$ as the subjects ascended $(\mathrm{p}<0.0005)$. At 5,000 m (median number of coughs 5 , range $0-13$ ) the NCF was between 1.7 and 10 times $(95 \% \mathrm{CI})$ the sea level value, and at 7,000 $\mathrm{m}$ (median number of coughs 12 , range $8-32$ ) the $\mathrm{NCF}$ was between 6 and 39 times the sea level value. On return to $5,000 \mathrm{~m} \mathrm{NCF}$ fell in comparison with $7,000 \mathrm{~m}$

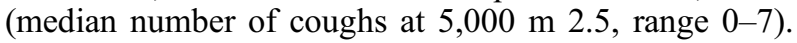
Ascent to $8,000 \mathrm{~m}$, with nights spent at $7,000 \mathrm{~m}$, resulted in a further rise in NCF in comparison with the return to $5,000 \mathrm{~m}$ (median NCF at $8,000 \mathrm{~m} 12$ coughs, range 332 ), but was not significantly different from NCF at 7,000 $\mathrm{m}$ (95\% CI $0.3-2.5$ times the 7,000 m NCF). NCF fell with the return to sea level (median 0, range $0-1$ ).

\section{Citric acid cough challenge}

The CACT (fig. 2) was unchanged at both $5,000 \mathrm{~m}$ (GMD) $1.0,95 \%$ CI $0.5-2.1, \mathrm{p}=0.5$ ) and the return to 5,000 $\mathrm{m}$ in comparison with sea level (GMD $0.8,95 \%$ CI $0.3-2.1$, $\mathrm{p}=0.35$ ) and there was no difference between the first stay

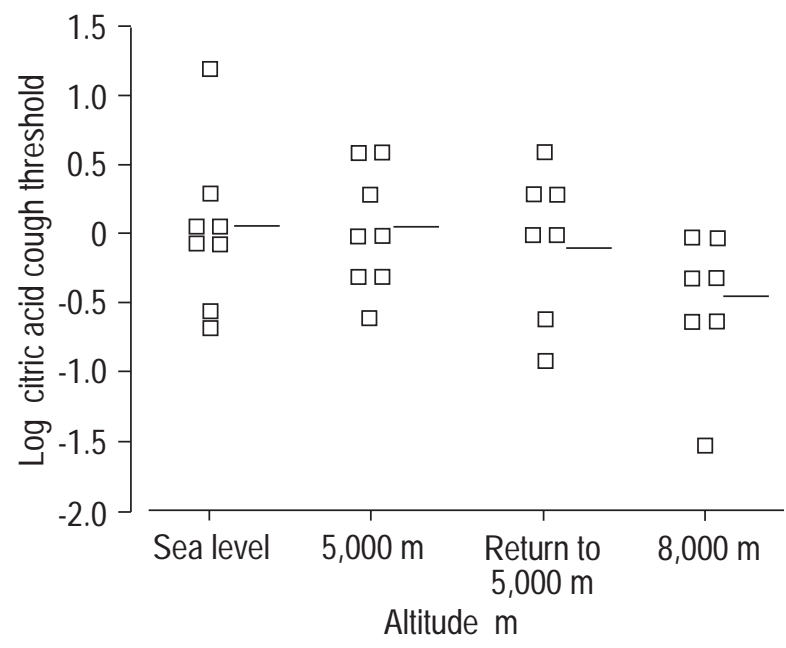

Fig. 2. - Log (citric acid cough threshold) against altitude. The figure shows the $\log$ of the individual citric acid cough thresholds at each altitude, including sea level for the eight subjects. The geometric means are represented by the solid horizontal bars. 
at 5,000 $\mathrm{m}$ and return to 5,000 $\mathrm{m}$ (GMD $0.8,95 \%$ CI $0.5-$ 1.5, $\mathrm{p}=0.261$ ). The cough threshold was, however, reduced at $8,000 \mathrm{~m}$ in comparison with both sea level (GMD $0.3,95 \%$ CI $0.1-0.95, \mathrm{p}=0.043$ ) and arrival at 5,000 m (GMD 0.35, 95\% CI 0.15-0.8, p=0.047). CACT, and prechallenge spirometric values, AMS score and oxygen saturation are given in table 3 .

AMS score increased with altitude, and at $8,000 \mathrm{~m}$ all subjects had scores of $\geq 3$. $S \mathrm{a}, \mathrm{O}_{2}$ fell to a mean of $86 \%$ at $5,000 \mathrm{~m}$ and $68 \%$ at $8,000 \mathrm{~m}$. At $8,000 \mathrm{~m}$ PEF increased by a mean of $27 \%$, FVC fell by $6.8 \%$ and FEV 1 was unchanged. These changes in spirometry are in keeping with previous reports [14]. Citric acid challenge did not produce a significant fall in FEV1 in comparison with prechallenge values. There was no statistically significant relationship between CACT and the AMS score or $\mathrm{Sa}_{2} \mathrm{O}_{2}$.

\section{Discussion}

The authors have previously [6] demonstrated a significant increase in the frequency of nocturnal cough and a decrease in the CACT in a group of 42 subjects ascending

Table 3. - Citric acid cough threshold, and prechallenge spirometric values, acute mountain sickness (AMS) score and arterial oxygen saturation $\left(\mathrm{Sa}, \mathrm{O}_{2}\right)$

\begin{tabular}{|c|c|c|c|c|c|c|c|}
\hline $\begin{array}{l}\text { Alti- } \\
\text { tude } \\
\mathrm{m}\end{array}$ & $\begin{array}{c}\text { Subject } \\
\text { No. }\end{array}$ & $\begin{array}{l}\text { Cough } \\
\text { threshold } \\
\log \left[\mathrm{g} \cdot \mathrm{L}^{-1}\right]\end{array}$ & $\begin{array}{c}\text { FVC } \\
\mathrm{L}\end{array}$ & $\begin{array}{c}\text { FEV1 } \\
\mathrm{L}\end{array}$ & $\begin{array}{l}\mathrm{PEF} \\
\mathrm{L} \cdot \mathrm{s}^{-1}\end{array}$ & $\begin{array}{l}\text { AMS } \\
\text { score }\end{array}$ & $\begin{array}{c}\mathrm{Sa}_{\mathrm{a}} \mathrm{O}_{2} \\
\%\end{array}$ \\
\hline \multirow[t]{8}{*}{0} & 1 & 0.0 & 5.1 & 4.2 & 10.4 & 0 & 99 \\
\hline & 2 & 1.2 & 5.0 & 3.8 & 8.2 & 0 & 99 \\
\hline & 3 & 0.0 & 6.0 & 4.9 & 8.9 & 0 & 98 \\
\hline & 4 & 0.3 & 6.4 & 5.0 & 12.0 & 0 & 98 \\
\hline & 5 & 0.6 & 6.0 & 5.0 & 8.7 & 0 & 99 \\
\hline & 7 & -0.6 & 5.0 & 4.4 & 13.0 & 0 & 98 \\
\hline & 8 & 0.0 & 4.8 & 4.2 & 9.0 & 0 & 98 \\
\hline & 9 & 0.0 & 4.1 & 3.1 & 8.8 & - & 98 \\
\hline \multirow[t]{8}{*}{5,000} & 1 & 0.6 & 5.4 & 4.6 & 12.2 & 0 & 84 \\
\hline & 2 & 0.3 & 4.9 & 4.0 & 11.2 & 3 & 86 \\
\hline & 3 & 0.0 & 5.9 & 5.4 & 10.3 & 0 & 87 \\
\hline & 4 & 0.6 & 6.5 & 5.1 & 14.5 & 0 & 84 \\
\hline & 5 & -0.3 & 5.9 & 5.1 & 10.7 & 1 & 85 \\
\hline & 7 & -0.6 & 4.8 & 4.4 & 14.0 & 1 & 84 \\
\hline & 8 & -0.3 & 5.0 & 4.4 & 11.5 & 0 & 82 \\
\hline & 9 & 0.0 & 3.6 & 2.9 & 9.3 & 0 & 86 \\
\hline \multirow{8}{*}{$\begin{array}{l}\text { Return } \\
\text { to } 5,000\end{array}$} & 1 & 0.3 & 5.4 & 4.7 & 11.6 & 0 & 88 \\
\hline & 2 & 0.0 & 4.7 & 3.9 & 10.3 & 1 & 86 \\
\hline & 3 & 0.0 & 5.8 & 5.3 & 10.3 & 0 & 86 \\
\hline & 4 & 0.6 & 5.8 & 5.1 & 11.0 & 2 & 88 \\
\hline & 5 & -0.6 & 5.9 & 5.2 & 10.9 & 1 & 92 \\
\hline & 7 & -0.9 & - & - & - & 0 & 88 \\
\hline & 8 & 0.3 & 4.8 & 4.4 & 12.6 & 0 & 87 \\
\hline & 9 & - & - & - & - & 0 & 88 \\
\hline \multirow[t]{8}{*}{8,000} & 1 & - & - & - & - & - & - \\
\hline & 2 & -0.6 & 4.4 & 3.6 & 11.5 & 1 & 80 \\
\hline & 3 & -0.3 & 5.7 & 5.4 & 12.1 & 6 & 70 \\
\hline & 4 & -0.3 & 5.6 & 4.7 & 14.7 & 6 & 67 \\
\hline & 5 & -1.5 & 5.6 & 5.0 & 11.9 & 7 & 69 \\
\hline & 7 & -0.6 & 4.9 & 4.4 & 15.2 & 7 & 57 \\
\hline & 8 & 0.0 & 4.3 & 4.1 & 12.4 & 6 & 66 \\
\hline & 9 & 0.0 & 4.1 & 3.3 & 8.9 & 10 & 66 \\
\hline
\end{tabular}

FVC: forced vital capacity; FEV1: forced expiratory volume in one second; PEF: peak expiratory flow. to Everest Base Camp at 5,300 $\mathrm{m}$ in the Nepalese Himalaya. The changes in NCF were most obvious in a subgroup of three climbers ascending to $7,000 \mathrm{~m}$ or above. The present study has confirmed those findings and extended them in a larger group to the extreme altitudes above $7,000 \mathrm{~m}$, with climatic conditions which were controlled throughout the duration of the study. This study, therefore, refutes the hypothesis that high altitude cough is due to changes in inspired air temperature or humidity.

Despite the present findings, drying of the respiratory mucosa, which is known to precipitate cough $[15,16]$, may still have occurred, not through the inhalation of cold, dry air, but because the increase in ventilation at altitude in response to hypoxia requires larger volumes of air to be warmed and humidified than at sea level. Unfortunately, the only studies measuring respiratory water loss at altitude have been confined to exercise [17-19] while the measurements made in this study were at rest. In addition, ANDERSEN et al. [20] have demonstrated that nasal breathing at sea level was able to satisfactorily condition air inspired at $23^{\circ} \mathrm{C}$ and with a relative humidity of $9 \%$ even at high minute volumes (up to $107 \mathrm{~L} \cdot \mathrm{min}^{-1}$ ). It is not known how altitude effects the ability of the upper respiratory tract to condition inspired air.

Cough may be the sole symptom of asthma. Although bronchoconstriction has been demonstrated after hyperpnoea with cold air [21], it is dissociated from the cough reflex, being abolished by pretreatment with $\beta_{2}$-agonists, which had no effect on cough [22]. Likewise bronchodilator therapy does not alter the CACT in nonasthmatic subjects [23]. In the present study, the change in cough threshold was not associated with changes in FEV1 or PEF and these findings do not support a role for bronchoconstriction in cough at high altitude.

Most subjects ascending to high altitude almost certainly develop a degree of subclinical interstitial pulmonary oedema [24, 25]. While it is generally considered that pulmonary oedema causes cough, and one of the recognized symptoms of HAPO is cough [26, 27], there are, to the authors' knowledge, no controlled studies demonstrating a clear relationship between pulmonary oedema and cough. In addition, the major known anatomical sites which stimulate cough are located above the segmental airways (division 4) [28]. However, there is growing evidence that inflammatory processes $[29,30]$ and alterations in vascular permeability occur throughout the body upon exposure to high altitude [31, 32], often without any symptoms. If subclinical pulmonary oedema is a result of an overall increase in vascular permeability, changes around rapidly acting pulmonary receptors might produce a change in the cough threshold. The fall in FVC with altitude supports the suggestion that mild pulmonary oedema occurred in these subjects.

There was no relationship between AMS score or hypoxia (as indicated by oxygen saturation) and change in CACT. This does not exclude a relationship between cough and AMS, as it may simply mean that the numbers were too small to detect changes, particularly at the low AMS scores seen in the study.

One of the changes seen during acclimatization to high altitude is an increase in the hypercapnic ventilatory response (HCVR) [33]. BANNER [34] has demonstrated a relationship between HCVR and cough threshold to hypotonic saline, with those subjects with the greatest HCVR 
having the lowest cough threshold, suggesting that there may a role for the "cough centre" in the changes seen in cough threshold at high altitude. This is supported from observational data from high altitude [35].

The increase in cough seen in this study may be owing to changes at any point in the cough reflex arc. At sea level the commonest precipitants of cough are upper respiratory tract infections, environmental irritants, and in particular cigarette smoke [36]. The subjects in the study demonstrated no evidence of respiratory tract infection. Although three subjects were occasional smokers before entry into the chamber, smoking during the duration of the study was not permitted. Air quality at high altitudes in the mountains is generally of a considerably higher quality than at sea level and is relatively free of allergens. It is unlikely therefore that inhaled irritants are responsible for high altitude cough.

The logistics of a hypobaric chamber study limit the sample size, and restricted the ability to answer the questions posed in this study. Using data from a previous study [6], it was estimated that nine subjects would be needed to demonstrate a significant fall in the cough threshold with a study power of $80 \%$ [37]. It was only possible to accommodate eight subjects in the chamber, and a number of data points were missed owing to either subject illness or logistical problems. This means that a change in the cough threshold at lower altitudes may have been missed, and limits the ability to explore relationships between cough and lung function.

The other difference from the authors' previous study is that the change in CACT only becomes significant at 8,000 $\mathrm{m}$, whereas previously a change was demonstrable after acclimatization to $5,000 \mathrm{~m}$. Airway deposition of inhaled particles changes with air density [38], and it is possible that the increase in the cough threshold seen at $8,000 \mathrm{~m}$ is due to changes in the amount of citric acid delivered to the cough receptors. In contrast, NCF varies strikingly with altitude, increasing on ascent to $7,000 \mathrm{~m}$, decreasing on descent to $5,000 \mathrm{~m}$, and then increasing again on return to $7,000 \mathrm{~m}$ and above. This suggests the possibility of a direct relationship between cough and altitude, independent of any tests using a tussive stimulus.

In summary, an increase in cough frequency and cough receptor sensitivity was demonstrated on simulated ascent to $8,000 \mathrm{~m}$, despite controlled inspired air temperature and humidity. This study refutes the hypothesis that high altitude cough is simply due to the prolonged inhalation of cold, dry air. The small sample size makes further conclusions difficult, and the cause of altitude-related cough remains unclear.

\footnotetext{
Acknowledgements: The authors gratefully acknowledge the participation of the "altinauts", K. Bodin, E. Cauchy, G. Despiau, J-C. Finance, M. Gayet, V. Marchand, G. Sabin, P. Serpollet and A. Heretier, without whose dedication and cooperation the study would not hve been possible, the staff of COMEX, and of Clement Clarke International for the loan of the Sonix 2000 nebulizer.
}

\section{References}

1. Somervell TH. After Everest. London, Hodder and Stoughton, 1936.
2. Tasker J. Everest the Cruel Way. London, Eyre Methuen, 1981.

3. Steele P. Medicine on Mount Everest 1971. Lancet 1971; ii: $32-39$.

4. Murdoch DR. Symptoms of infection and altitude illness among hikers in the Mount Everest region of Nepal. Aviat Space Environ Med 1995; 66: 148-151.

5. Ward MP, Milledge JS, West JB. High Altitude Medicine and Physiology, 2nd edn. London, Chapman and Hall, 1995; p. 390.

6. Barry PW, Mason NP, Riordan M, O'Callaghan C. Cough frequency and cough receptor sensitivity are increased in man at altitude. Clin Sci 1997; 93: 181-186.

7. Banner AS, Chausow A, Green J. The tussive effect of hyperpnea with cold air. Am Rev Respir Dis 1985; 131: 362-367.

8. Altman DG. Practical Statistics for Medical Research. London, Chapman and Hall, 1991.

9. Ryan G, Dolovich MB, Obminski G, Cockroft DW, Juniper E, Hargreaves FE. Standardisation of inhalation provocation tests: influence of nebuliser output, particle size and method of inhalation. J Allergy Clin Immunol 1981; 67: 156-161.

10. Barros MJ, Zammattio SJ, Rees PJ. Importance of inspiratory flow rate in the cough response to citric acid inhalation in normal subjects. Clin Sci 1990; 78: 521-525.

11. Pounsford JC, Saunders KB. Diurnal variation and adaption of the cough response to citric acid in normal subjects. Thorax 1985; 40: 657-661.

12. Empey DW, Laitinen LA, Young GA, Bye CA, Hughes DTD. Comparison of the antitussive effect of codeine phosphate $20 \mathrm{mg}$, dextromethorphan $30 \mathrm{mg}$ and noscapine $30 \mathrm{mg}$ using citric acid induced cough in normal subjects. Eur J Clin Pharmacol 1979; 16: 393-397.

13. Hackett P. Lake Louise Consensus statement on the definition of altitude illness. In: Sutton JR, Coates G, Houston CS, eds. Hypoxia and Mountain Medicine. Burlington, CS Houston, 1992; pp. 327-330.

14. Pollard AJ, Mason NP, Barry PW, et al. Effect of altitude on spirometric parameters and the performance of peak flow meters. Thorax 1996; 51: 175-178.

15. Irwin RS, Rosen MJ. Cough: a comprehensive review. Arch Intern Med 1977; 137: 1186-1191.

16. Banner AS, Green J, O'Conner M. Relation of respiratory water loss to coughing after exercise. N Engl J Med 1984; 311: 833-836.

17. Pugh LGCE, Gill MB, Lahiri S, et al. Muscular exercise at great altitude. J Appl Physiol 1964; 19: 431-440.

18. West JB, Boyer SJ, Graber DJ, et al. Maximal exercise at extreme altitudes on Mount Everest. J Appl Physiol 1983; 55: 688-698.

19. Ward MP, Milledge JS, West JB. High Altitude Medicine and Physiology, 2nd edn. London, Chapman \& Hall, 1995; p. 478.

20. Andersen I, Lundqvist GR, Jensen PL, Proctor DF. Human response to 78-hour exposure to dry air. Arch Environ Health 1974; 29: 319-324.

21. Strauss RH, McFadden ER, Ingram RH, Jaegar JJ. Enhancement of exercise-induced asthma by cold air. $N$ Engl J Med 1977; 297: 743-747.

22. Pounsford JC, Birch MJ, Saunders KB. Effect of bronchodilators on the cough response to citric acid in normal and asthmatic subjects. Thorax 1985; 40: 662-667.

23. Belcher N, Rees PJ. Effects of pholcodine and salbutamol on citric acid induced cough in normal subjects. Thorax 1986; 41: 74-75.

24. Gray GW, McFadden MD, Houston CS, Bryan AC. 
Changes in the single-breath nitrogen washout curve on exposure to 17,600 ft. J Appl Physiol 1975; 39: 652-656.

25. Kronenburg RS, Safar P, Lee J, et al. Pulmonary artery pressure and alveolar gas exchange in man during acclimatisation to $12,470 \mathrm{ft}$. J Clin Invest 1971; 150: 827 837.

26. Richalet J-P. High altitude pulmonary oedema: still a place for controversy? Thorax 1995; 50: 923-929.

27. Peacock AJ. High altitude pulmonary oedema: who gets it and why? Eur Respir J 1995; 8: 1819-1821.

28. Widdecombe JG. Neurophysiology of the cough reflex. Eur Respir J 1995; 8: 1193-1202.

29. Maggiorini M, Bartsch P, Oelz O. Association between raised body temperature and acute mountain sickness: cross sectional study. Br Med J 1997; 315: 403-404.

30. Schoene RB, Swenson ER, Pizzo CJ, et al. The lung at high altitude: bronchoalveolar lavage in acute mountain sickness and pulmonary oedema. J Appl Physiol 1988; 64: 2605-2613.

31. Hansen JM, Olsen NV, Feldt-Rasmussen B, et al. Albuminuria and overall capillary permeability of albumin in acute hypoxia. J Appl Physiol 1994; 76: 1922-1927.
32. Richalet J-P, Hornych A, Rathat C, Aumont J, Larmignat P, Remy P. Plasma prostaglandins, leukotrienes and thromboxane in acute high altitude hypoxia. Respir Physiol 1991; 85: 205-215.

33. Kellog RH. The role of $\mathrm{CO}_{2}$ in altitude acclimatization. In: Cunningham DJC, Lloyd BB, eds. The Regulation of Human Respiration. Oxford, Blackwell Science, 1963; pp. 379-394.

34. Banner AS. Relationship between cough due to hypotonic aerosol and the ventilatory response to $\mathrm{CO}_{2}$ in normal subjects. Am Rev Respir Dis 1988; 137: 647-650.

35. Barry PW, Mason NP, Nickol A, et al. Cough receptor sensitivity and dynamic ventilatory response to carbon dioxide in man acclimatised to high altitude (Abstract). $J$ Physiol 1996; 497P: 29-30.

36. Irwin SI, Rosen MJ, Braman SS. Cough: a comprehensive review. Arch Intern Med 1997; 137: 1186-1191.

37. Campbell MJ, Machin D. Medical Statistics: A Common Sense Approach. Chichester, John Wiley \& Sons, 1994.

38. Lippman M, Esch J. Effect of lung airway branching pattern and gas composition on particle deposition. Exp Lung Res 1988; 14: 311-320. 